Pluricentricity and heritage language maintenance of Arab immigrants in the English speaking New World countries

\author{
Alsahafi, Morad $\bowtie$ \\ King Abdulaziz University, Saudi Arabia (m.alsahafi@gmail.com) \\ Received: 3 April 2017 \\ Available Online: 8 May 2017 \\ Revised: 12 April 2017 \\ DOI: $10.5861 /$ ijrsll.2017.1795
}

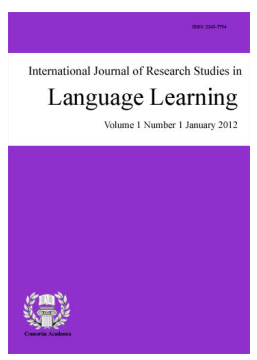

ISSN: 2243-7754 Online ISSN: $2243-7762$

\title{
Abstract
}

Historical accounts of immigration from the Arab world show that Arab immigrants ended up in different New World destinations including North America, Australia, and New Zealand. The present review intended to be representative of studies on Arabic language contact and maintenance in English speaking New Word countries. As a pluricentric language (Abd-el-Jawad, 1992; Clyne \& Kipp, 1999), Arabic has been brought to English speaking New Word countries by Arab immigrants from a range of different Arab countries. The Arabic language and its role in the formation of pan-Arab nationalism or Arabness throughout the Arab world seem to have an impact on the dynamics of Arabic language contact in immigrant multilingual contexts. The review indicates that Arabic pluricentricity plays an important role in creating a sense of "shared Arabness" among different Arabic-speaking immigrant groups. As a base of networking, the Arabic language provides one aspect of commonality for Arab immigrants that transcends other possible aspects such as religion and country of origin. Thus, Arabic operates as an important identity marker that seems to bring Arabic speaking immigrants together to establish their own ethnic associations and arrange for a variety of community events and activities conducive to heritage language maintenance.

Keywords: Arab; Arabic; immigrant; language maintenance; pluricentricity; heritage language 


\section{Pluricentricity and heritage language maintenance of Arab immigrants in the English speaking New World countries}

\section{Introduction}

Immigration represents the third major component of population change, after births and deaths (Lewis, 1982). People migrate, either voluntarily or involuntarily, intra- or internationally, for different motives. Broadly speaking, social scientists usually make a useful general distinction between the "push" and "pull" factors of migration (Meilaender, 2001). Push factors refer to those forces of expulsion that make people leave their country in search of a better life. Such push factors include religious persecution, hard economic conditions, civil strife, and political unrest in the homeland. On the other hand, pull factors are those forces that attract people towards a particular country in order to settle themselves in a more attractive environment. Pull factors include seeking economic improvement, joining other family members (known as chain migration), and favourable migratory policies in the receiving country. In many cases of migration, however, it could be a complex combination of both push and pull factors that stimulate an individual or a group of people to leave their home for another country. The following section provides an overview of Arab immigration to "New World" destinations, particularly to such English-speaking countries as the United States, Canada, Australia and New Zealand.

\subsection{Arab immigration to the New World}

Arab immigration to and settlement in the "New World" is not a new phenomenon (Aboud, 2000; Elkholy, 1966; Rouchdy, 2002). Waves of Arab immigration took place before and after World War II for various reasons. Historical accounts of immigration from the Arab world show that Arab immigrants ended up in different New World destinations including North America, Australia, and New Zealand (Aboud, 2000). Khalaf (1987, cited in Harp, 1998) gives six general reasons for Arab immigration: (a) economic and demographic pressures experienced by members of lower socioeconomic groups; (b) educated Arab groups seeking social equality, freedom and liberty; (c) religious persecution and sectarian violence; (d) the role of missionaries and their established schools in some Arab countries such as Syria and Lebanon leading many young Arabs to leave their home countries in pursuit of a better life; (e) steamship agents' labour recruitments; and finally (f) success stories of returning immigrants. According to Harp (1998), major causes of Arab immigration include Lebanese Civil war, the Arab-Israeli conflict, political unrest in Yemen, and the 1990-1991 Gulf crises. More recently, the outbreak of what has become to be known as the Arab Spring and its tragic consequences has led to large scale migration from the Arab World.

According to Aboud (2000), the United States, Australia, Canada, and New Zealand share a number of commonalities as modern immigrant-receiving states including:

$>\quad$ their common origins as colonies of European settlement;

$>\quad$ their histories of dominating the original inhabitants of their territories;

$>\quad$ the vital role played by immigration in their demographic and industrial growth;

$>\quad$ the historical influence of English legal and governmental practice on the development of their politico-juridical institutions;

$>\quad$ their ongoing role as immigration countries (p. 655).

As Arab immigrant-receiving countries, these English-speaking countries represent immigrant contexts 
where Arabic has been in contact with English. Arabic-speaking groups in these countries have many commonalities with each other (Aboud, 2000; Cruickshank, 2008). Immigrant Arabic-speaking communities are microcosms of the Arab world because they include Arab immigrants from different political, economic, religious, and linguistic (different spoken Arabic dialects) backgrounds. In such contexts of language contact, Arabic is the language spoken by a minority group of Arab immigrants while English is the dominant and most widely used language in the society.

\section{Arabic as a pluricentric language}

According to Clyne (1989), the concept of pluricentricity indicates that "a language has more than one centre, i.e., several centres, each providing a national variety with its own norm" (p. 358). Key characteristics of pluricentric languages include:

$>$ Occurrence: A certain language occurs in at least 2 nations;

$>\quad$ Linguistic distance: The variety must have enough linguistic (and/or pragmatic) characteristics that distinguish it from others and by that can serve as a symbol for expressing identity and social uniqueness;

$>\quad$ Status: The language must have an official status in at least two nations;

$>\quad$ Acceptance of pluricentricity: The language community must accept the status of its language as a pluricentric variety and consider it as part of its social/national identity;

$>\quad$ Relevance for identity: The national norm has to be relevant to social identity (Clyne, 1992, p. 1; Muhr, 2012, pp. 29-30).

Based on these criteria, the following languages are considered pluricentric since each of them has at least two national varieties: Arabic, Armenian, Chinese, Dutch, English, French, German, Hindi-Urdu, Korean, Malay, Spanish, Portuguese, Tamil, and Swedish (Clyne, 1992). To these, Muhr (2012) added Albanian, Greek, Guaraní, Hindi, Italian, Russian, Persian, and Rumanian-Moldovan.

The Arab world comprises the following 22 countries of the Arab league: Jordan, United Arab Emirates, Bahrain, Tunisia, Algeria, Djibouti, Saudi Arabia, Sudan, Syria, Somalia, Iraq, Oman, Palestine, Qatar, Comoros, Kuwait, Lebanon, Libyan Arab Jamahiriya, Egypt, Morocco, Mauritiana, and Yemen. Besides Standard/literacy Arabic which functions as the official language of these countries, each country develops its own spoken Arabic variety (e.g. Egyptian Arabic, Lebanese Arabic, Moroccan Arabic, etc). This type of sociolinguistic arrangement (known as classic diglossia) is observed in Arabic-speaking communities due to the co-existence of the standard literary variety (the H-variety), called "al-lugah al-fusha," and the colloquial variety (L-variety), called "al-lugah al-aammiyya" (see Alsahafi, 2016, for an overview of diglossia in Arabic).

The close association between language and national identity was very clearly articulated in the work of Arab nationalist scholars such as Sati al-Husari (1882-1968): "Every Arabic-speaking people is an Arab people. Every individual belonging to one of these Arabic-speaking peoples is an Arab" (Dawisha, 2003, p. 72). Developed at the turn of the $20^{\text {th }}$ century, Arab nationalism, which was inspired by the $19^{\text {th }}$-century German Romantic nationalism (Dawisha, 2003), emphasized the role of language in the formation of ethnic nationalism among Arabic-speaking peoples (pan-Arabism), living in a vast geographical region stretching from the Atlantic shores of Morocco to the Arabian Gulf.

Clearly then in the development of ethnic nationalism, the Arabic language (both in its standard and nonstandard forms) plays a central role. Abdua-Jawad (1992) argues that the situation in the Arab world provides an example of duality in nationalism. Accordingly, Abdul-Jawad makes a useful distinction between two national loyalties exhibited among Arabic speakers: A pan Arab national loyalty (feeling of Arabness), and a narrower 
national identity to the individual Arab country (e.g. Egyptianness or Moroccanness). While Standard Arabic "serves the universal function of Arab identification" the spoken nonstandard Arabic variety serves "the regional function of identifying the speaker's background" (Ibid, p. 269).

In terms of Arabic speaking immigrant communities, the Arabic language and its role in the formation of pan-Arab nationalism or Arabness throughout the Arab world seem to have an impact on the dynamics of Arabic language contact in immigrant multilingual contexts. For example, as documented in studies of Arabic language contact in Australia, the United States, and New Zealand this sense of "shared Arabness" is also achieved to a considerable extent in the country of immigration, as will be discussed later in this paper.

Thus, as a pluricentric language (Abd-el-Jawad, 1992; Clyne \& Kipp, 1999), Arabic has been brought to English speaking New Word countries by Arabic-speaking immigrants from a range of different Arab countries. Although Arab immigrants belong to different national and religious backgrounds, it is a common place to refer to "Arab" or "Arab Muslim" immigrants as an entity (Elkholy, 1966; Rouchdy, 2002; Tayash \& Ayouby, 1992). In such immigrant contexts, Arabic acts as the prime marker of the national spirit and "it tends to be identified with a people, a culture, an approach to life" (Judge, 2000, p. 49). For example, in his study of Arab Muslim immigrants in the United States, Elkholy noted that Arab Muslim immigrants "feel a common cultural, religious, and linguistic bond, in addition to the geographical and historical connection, with the Arab countries" (1966, p. 49).

In his study of historical accounts on Arab immigration to the United States, Australia, and Canada, Aboud (2000) identifies two types of studies based on Arab immigrant population boundaries: Studies that broadly use the cultural-political "Arab" (e.g. Arab immigrants) or the linguistic-cultural "Arabic-speaking" referent (e.g. Arabic-speaking immigrants) due to the historical and cultural commonalities (sense of pan-Arabism and Arab nationalism) among this group, and studies that focus on specific national Arab groups (Lebanese, Palestinian, Moroccan) or specific sub-national groups or religious affiliations (Maronite, Berber, Coptic).

Aboud (2000) argues that the employment of such umbrella terms as "Arab" or "Arabic-speaking" when referring to immigration originating from the Arab lands has led to continuities in existing historical accounts on Arab world migration. For example, Rouchdy (2002) identified five waves of Arab immigration from the Arab World to the United States, with the first wave, consisting of mainly Arab Christians, occurring in the nineteenth century and the last wave arriving in the 1990s.

\section{Studies on Arabic heritage language contact and maintenance}

The situation of Arabic as an immigrant minority language in New World English-speaking countries has been the subject of a number of comprehensive studies (Alsahafi, 2015; Alsahafi \& Barkhuizen, 2008; Clyne \& Kipp, 1999; Cruickshank, 2008; Dweik, 1992; Dweik, Nofal, \& Qawasmeh, 2014; Elkholy, 1966; Rouchdy, 2002; Sawaie, 1992; Sawaie \& Fishman, 1985; Taft \& Cahill, 1989; Tayash \& Ayouby, 1992). The following subsections explore empirical research into Arabic-English language contact and maintenance in these major English-speaking countries of immigration. It should be noted, however, that the review is not meant to be exhaustive; rather, it is meant to be representative.

\subsection{Arabic in the United States}

Arabic-speaking immigrants started to arrive in the United States in large numbers at the turn of the nineteenth century (Sawaie \& Fishman, 1985). The majority of the early arrivals were Arab Christians coming mainly from Syria and what is now known as Lebanon. Two decades later, following their Christian countrymen, waves of Arab Muslim immigrants started to arrive in the United States (Elkholy, 1966). According to Elkholy (1966, p. 22), "the fear of losing their religion" in the new country was the major reason in delaying the immigration of Arab Muslims to the United States. Sawaie and Fishman (1985, p. 33) identified four reasons for Arab immigration to the United States including: (a) the economic lure in the new world and the poor economic 
Pluricentricity and heritage language maintenance of Arab immigrants in the English speaking countries

conditions in the old countries, (b) the political insecurity under the Ottoman rule at that time, (c) the desire by many to evade the universal army conscription instituted by the Turks in 1908, and (d) sectarian strife between disparate communities.

Although the Arabic language represents one of the major immigrant languages in the United States spoken by over six million, there appear to be few specialist investigations of the status of Arabic among Arab immigrants in the United States (for example Dweik, 1992; Rouchdy, 1992, 2002; Sawaie \& Fishman, 1985). Sawaie and Fishman (1985) examined some of the Arabic language maintenance efforts in the United States through their investigations of the use of Arabic in three institutions established by early Arab immigrants: (a) the periodical press, (b) places of worship, and (c) ethnic schools. In general, Sawaie and Fishman (1985) found that Arabic was gradually displaced by English in all these institutional domains. Three factors were suggested by the researchers that might jointly account for the reported gradual disappearance of Arabic in all of these settings: the relative small size of the Arabic speaking community, the social power associated with English and the resultant pressure towards Americanization and assimilation, and the lack of conscious national identity among early Arab immigrants.

Another key study of Arabic maintenance in the United States is Dweik (1992). Based on a questionnaire designed to gauge Arabic maintenance amongst fifty Christian Lebanese immigrants, Dweik found that English was more widely used by all participants in a variety of domains. In addition, attitudes were more positive towards English than Arabic. Participants, for example, reported that "English was more beautiful and useful than Arabic." Dweik (1992) discussed two major factors that led Lebanese Christian immigrants in the city of Buffalo to shift almost completely to English: (a) communal factors such as length of residence in the foreign country, intermarriages, high educational and economic status, and weak contacts and ties with the home country; and (b) psychological factors including attitudinal changes towards Arabic and a change in functional language use. Dweik concluded by saying that "Arabic was abandoned because it had no religious or nationalistic value to these Lebanese" $(1992,117)$.

By and large, earlier studies of Arabic maintenance and shift among mainly Christian Arab Americans concluded that Arabic is maintained by the first and second generations but dies out amongst the third and fourth generations. These studies showed that Arabic is not effectively transmitted from one generation to the next and predicted that such intergenerational language loss would, sooner or later, lead to Arabic disappearance. As Sawaie puts it, "Unless minorities control their own cultural boundaries and maintain a degree of compartmentalization in their family, religious, and educational institutions, current language maintenance efforts are likely to end the same way they did among early Arabic-speaking citizens" (1992, p. 95).

However, in her more recent investigation of the situation of Arabic in Detroit, Rouchdy (2002) shows a change in the assessment and prediction of the fate of Arabic as an immigrant language in the United States. Rouchdy argues that there has been a revival in the use of Arabic among Arab Americans. She relates the revival in the Arabic language and "pan-Arab" identity (and other American ethnic minority languages in general) to three major social changes that favoured language and ethnicity maintenance among Arab Americans (2002, p. 142):

> The American Civil Rights Movement (1955-1968) encouraged the assertion and maintenance of racial, ethnic, gender and religious identity, as opposed to the traditional concept of the American "melting pot" which led to the Americanization and assimilation of early Arab immigrants;

$>$ Political unrest which erupted in many parts of the Arab world led to the continued arrival of new Arabic-speaking immigrants to the United States, many of whom were well-educated. Continued arrival of new Arab immigrants has increased the opportunities to use Arabic in a larger immigrant social context;

The revival of Muslim identity in the Arab world and among Arab-Muslim Americans has revitalized 
the important role played by the Arabic language as a symbol of the Muslim identity and as the liturgical language of Islam used when reading the Qur'an, performing daily prayers, and during Friday noon prayers. In addition, the wearing of Islamic hijab or proper Islamic attire, as a symbol of Muslim woman identity, has increased among American Muslim women.

According to Rouchdy (2002), this process of Arabic revival is evident in the increasing institutional support Arabic started to receive as reflected in the increasing number of various types of Arabic-language media that transmit from the Arab world, the establishment of national religious and private schools where Arabic and Islamic studies are taught, and in the increasing popularity of and enrolment in Arabic classes at higher education institutions. As Rouchdy (2002) rightly points out, formal learning of Standard Arabic, which acts as a unifying force and a shared code between Arab Americans, supports the maintenance of Arabic spoken varieties because these two varieties of Arabic, i.e. standard and non-standard, are genetically related and coexist in a diglossic relationship. Rouchdy also notes that a new ethnic dialect or lingua franca develops among Arab Americans as a result of constant double language contact between Standard Arabic and Arabic dialects on the one hand and between different Arabic dialects themselves on the other hand. This lingua franca does not correspond to any Arabic variety and it is only used and understood by Arab Americans.

\subsection{Arabic in Canada}

In Canada, Arabic is spoken as a first language by 470,965 in 2011 constituting 1.2 of the total population of the country (Canada Census, 2011). These Arabic speakers come from all the countries of the Arab world with the majority originating from Lebanon, Egypt, Morocco, Iraq, Algeria, and Syria.

Dweik, Nofal, and Qawasmeh (2014) explored patterns of language use and attitudes among 70 Muslim Arabs representing different age groups (14-59) and all living in Vancouver. Data were collected by using a sociolinguistic questionnaire. The results of language use analysis indicated that both Arabic and English are used side by side and in different domains by the participants. Arabic was reported to be the language widely used in such domains as the family, friendship, religion, Arabic school and media. English was reported to be used mostly in the workplace. In terms of language attitudes, the participants showed very positive attitudes toward Arabic as the language of the Holy Quran as well as a symbol of their ethnic and national identity. They also held positive attitudes towards English due to its perceived usefulness as well as its status as an official language.

In another recent study, Dweik and Qawar (2015) investigated patterns of language choice and attitudes among 100 Arabs living in Quebec-Canada. Constituting 2.2\% of the population of Quebec, the Canadian Arabs of Quebec were able to establish many religious centres (e.g. mosques, churches) and Arabic schools. Generally, the findings showed that the participants had positive attitude towards Arabic, English and French as these languages allowed them to express both their Arab ethnic and Canadian identity. Analysis of patterns of language choice showed that while Arabic is widely used in such private domains of the home and the place of worship, English and French are employed in the two formal domains of government and education. In addition, these languages were reported to be mixed in the domains of neighborhood, friendship and media.

\subsection{Arabic in Australia}

Australia represents another multicultural environment in which a large number of immigrant groups live. Spoken as a first language by 264,400 in 2011, Arabic is ranked as the fourth main language spoken in Australia (ABS, 2011). Of these, 38.5\% are Australian born. In this section, some representative Arabic maintenance studies conducted in the Australian context will be reviewed. Taft and Cahill (1989) investigated the relative use of Arabic (L1) and English (L2) and competence in these languages among 62 Lebanese school children aged 10 to 11 in Melbourne. The families had been in Australia for a median period of 10 years. Most of the children had received all their schooling in Australia. Language tests were administered to measure the children's 
competencies both in Arabic and English. In addition, the children and their parents were interviewed. The children were found to be dominant in English in all of the four skills. For example, $94 \%$ of the children reported that they understood English well as opposed to only 61\% in Arabic. The children's superiority in English over Arabic was found to be greater in the reading and writing modes. For example, while almost all the children $(94 \%)$ had confidence in their ability to read English "well”, only 6\% did so in Arabic. In general, English was found to be the dominant language of the Lebanese immigrant children. Length of residence in Australia, parental pressures, and children's attitudes were all found to have an influence on children's competence in Arabic. Based on their findings, the researchers concluded that the fate of Arabic among Lebanese immigrant children in Melbourne was not promising in terms of both oral and literacy skills especially in the absence of Arabic written materials in most of the immigrants' homes.

In another study into Arabic-English language contact in the Australian context, Clyne and Kipp (1999) used questionnaires and focus group discussions to investigate patterns of language maintenance and shift among Egyptian and Lebanese immigrants. In general, findings revealed some intergenerational differences in both groups with regard to language use and language proficiency. For example, older participants (over the age of 35) tended to use more Arabic than their younger counterparts. Regarding reported Arabic proficiency, older informants showed higher confidence in all language skills than younger respondents who reported less proficiency for all skills and particularly for literacy skills (reading and writing). Attitudes towards Arabic maintenance were positive by most of the informants who demonstrated high support for the maintenance of Arabic and ethnic identity. However, such support was slightly weaker amongst the second generation.

According to Clyne and Kipp (1999, pp. 331-332), a common sense of "shared Arabness" is achieved among members of the Arabic-speaking community in Australia due to a number of factors. Firstly, there is a need for the different Arab immigrant groups to form a larger community with a common language in the country of immigration and to work together in order to compete with other ethnic groups for available multicultural resources such as ethnic school funding and ethnic radio transmission. Secondly, Arab immigrants share a common experience and their collective position as a group with a shared code is influenced by events taking place in the Arab world such as the Gulf War. As a result, the rehabilitation of the image of their community demands collective actions. Thirdly, the Arabic language acts as a unifying force and consequently contributes to Arab immigrants' sense of "shared Arabness."

In a recent review of Arabic-English bilingualism and research into Arabic language contact in the Australian context, Cruickshank (2008) reported that Arabic is widely used in a number of key domains including the home, the community, religion and in the media. Arabic is reported as one of the most widely used community languages in the home domain in Australia (Clyne, 2003). For example, Arabic is overwhelmingly used among parents and when speaking to children. Reading the Qur'an with children, telling them stories related to the Qur'an and enrolling children in Qur'anic and religious classes represent common literacy practices among Arab Muslim families in Australia. On the other hand, English is reported as the preferred language used for communication among siblings and teenagers. Children and teenagers are also reported to develop a mixed code of Arabic and English.

At the community level, Arabic is widely employed in a range of Arabic speaking businesses such as food shops, bookshops and other retail outlets, and with a range of professionals such as doctors and accountants. As far as media use among Arabic-speaking families is concerned, Cruickshank (2008) noted a high usage of Arabic media including cable and Arabic satellite TV channels, Arabic radio, Arabic language videos, and Arabic internet sites. In addition, there is a high reported use of Arabic printed materials in local libraries and Arabic language newspapers. Arabic is also reported as one of the community languages taught in day schools and in a number of specialist schools of languages in NSW and Victoria where the majority of Arab immigrants live. Arabic is also taught in many governmentally supported Arabic community language schools.

While describing the process of language shift among the Arabic-speaking community in Australia as 
variable and less than that for other community languages, Cruickshank (2008, pp. 289-290) concludes his review by emphasizing the possible impact of a number of local and international issues and factors on the current position and future of Arabic in Australia, including (a) the "war on terror", 9/11 and events in the Middle East; (b) increasing segmentation in schools based on students' socioeconomic and ethnic language backgrounds; (c) advances in transportation and communication technologies facilitating Arab immigrant families communication with and travel to their countries of origin; and (d) the establishment of community-based organizations and facilities such as community language schools, Arabic radio stations and religious organizations as the Arabic-speaking communities become more established. According to Cruickshank, such local and international issues and factors "will continue to have dramatic effects on school provision, uptake of language study and attitudes towards Arabic and Arabic speakers" (p. 289).

\subsection{Arabic in New Zealand}

Arabic-speaking immigrants represent a relatively recent immigrant community in New Zealand. Their number increased considerably during the mid-1990s, particularly after the Second Gulf War which took place in 1990-1991. Number of New Zealand census respondents identified their ethnic group as "Arabs" rose from 177 in 1991 to 2856 in the 2001 Census (Statistics New Zealand, 2002). Based on 2013 Census results, 2919 respondents identified themselves as "Arabs" and many others stated more specifically their ethnic group based on their country of origin such as Iraqi, Egyptian, Lebanese, Palestinian, Syrian, Jordanian, Tunisian, Yemeni, Algerian and Moroccan. Among the largest of these specific ethnic categories are Iraqi (2586), Egyptian (1110), and Lebanese (1044). Language data obtained from the 2013 census show that 10746 respondents claimed to be first-language Arabic speakers (Statistics New Zealand, 2013).

The situation of Arabic as a minority immigrant language has been the subject of a few studies (Al-Sahafi, 2015; Al-Sahafi \& Barkhuizen, 2006, 2008). Al-Sahafi and Barkhuizen (2006) investigated patterns of language proficiency and use among 63 adult Arab immigrants living in Auckland. Findings were based on data collected by using questionnaires and semi-structured interviews. Some intergenerational differences were noticed between older participants (over 35) and younger ones. That is, older respondents were found to be more confident in their Arabic skills across all areas than younger respondents, who showed a lower confidence particularly in their Arabic reading and writing abilities. In terms of patterns of language use, the respondents reported high frequency use of Arabic in such private domains as the home, friendship, and religion whereas English is more widely used in the public domain. In general, younger respondents reported more frequent use of English than their older counterparts. The important role of Arabic as a religious variety as well as the implementation of Arabic only at home policy were found to be two main factors conducive to language maintenance among the participants' families.

Al-Sahafi (2015) examined Arabic-English bilingual development among 10 Arabic-speaking immigrant children living with their families in Auckland. Findings based on interview and observational data showed that both the children and their families seemed to be aware of the rather unbalanced bilingual development among the children as they were gradually becoming proficient users of English, particularly after joining their English-only mainstream schools. Although the study showed that these children did maintain their spoken Arabic, i.e. the Arabic variety used by their parents, to a certain extent, their Arabic literacy skills were not equally developed due to a number of factors. Such factors include (a) limited exposure to reading and writing in Standard Arabic, (b) lack of opportunity to practise reading and writing in Arabic since English is the main literacy required for their mainstream education, and (c) Arabic diglossic nature as demonstrated in the influence of their spoken non-standard Arabic varieties, particularly among those children whose spoken variety diverges quite considerably from the written standard. Nevertheless, participant families reported the employment of several language maintenance strategies to help their children to maintain the Arabic language and culture, including, setting family language policy (e.g. Arabic only in home interactions), acquiring and using Arabic resources in the family, participation in ethnic community events and activities, and planning return visits to the homeland. 


\section{Conclusion}

The findings of the Arabic maintenance studies reviewed above show that the process of Arabic maintenance is a complex one and does not occur in a vacuum. A wide range of macro and micro-level factors such as institutional support, numerical strength, policy in the immigration country, major events in the homeland and the world, diglossia, pluricentricity and the relationship between language and ethnic, national, and religious identity, to a more or lesser extent, all appear to influence the position of Arabic and its maintenance and transmission as an immigrant minority language.

In particular, the present review indicates that the pluricentric nature of Arabic, or "differing national norms" (Kipp, 2008, p. 76), appeared to have an influence on the process of Arabic heritage language maintenance. Arabic pluricentricity seems to play an important role in creating a sense of "shared Arabness" among different Arabic-speaking groups. In this connection, the Arabic language provides one aspect of commonality for Arab immigrants that transcends other possible aspects such as religion and country of origin and consequently facilitates the formation of coethinc social networks. As righty noted by Clyne and Kipp, "in a multicultural country of immigration, the absence of people with exactly the same background entails going 'further down the hierarchy' to establish your networks and this affords a greater role to the unifying force of language" (p. 332, 1999). Clearly, as a pluricentric language, Arabic operates as an important identity marker that tends to bring Arabic speaking immigrants together to establish their own ethnic associations and arrange for a variety of community events and activities conducive to heritage language maintenance.

\section{References}

Abd-el-Jawad, R. H. (1992). Is Arabic a pluricentric language? In M. Clyne (Ed.), Pluricentric languages (pp. 261-304). Berlin: Mouton de Gruyter.

Aboud, B. (2000). Re-reading Arab World-New World immigration history: beyond the prewar/postwar divide. Journal of Ethnic and Migration Studies, 26, 653-673. https://doi.org/10.1080/713680503

Al-Sahafi, M. (2015). The role of Arab fathers in heritage language maintenance in New Zealand. International Journal of English Linguistics, 5, 73-83. https://doi.org/10.5539/ijel.v5n1p73

Al-Sahafi, M. (2016). Diglossia: An overview of the Arabic situation. International Journal of English Language and Linguistics Research, 4, 1-11.

Al-Sahafi, M. A., \& Barkhuizen, G. (2006). Language use in an immigrant context: The case of Arabic in Auckland. New Zealand Studies in Applied Linguistics, 12, 51-69.

Al-Sahafi, M. \& Barkhuizen, G. (2008). Ethnic mother-tongue maintenance among Arabic speaking immigrants in New Zealand. Arab Journal for the Humanities, 26, 205-232.

Australian Bureau of Statistics, 2011. Language spoken (total persons). http://www.abs.gov.au

Clyne, M. (1989). Pluricentricity: National variety. In U. Ammon (Ed.), Status and function of languages and language varieties (pp. 357-371). Berlin: Walter de Gruyter.

https://doi.org/10.1515/9783110860252.357

Clyne, M. (1992). Pluricentric languages: Differing norms in different Nations. Berlin: Mouton de Gruyter.

Clyne, M. (2003). Dynamics of language contact. Cambridge: Cambridge University Press. https://doi.org/10.1017/CBO9780511606526

Clyne, M., \& Kipp, S. (1999). Pluricentric languages in an immigrant context: Spanish, Arabic and Chinese. Berlin/New York: Mouton de Gruyter. https://doi.org/10.1515/9783110805444

Cruickshank, K. (2008). Arabic-English bilingualism in Australia. In J. Cummins \& N. H. Hornberger (Eds.), Encyclopedia of language and education (2nd ed., Vol. 5: Bilingual education, pp. 281-291). New York: Springer Science+Business Media LLC. https://doi.org/10.1007/978-0-387-30424-3_131

Dawisha, A. (2003). Arab nationalism in the twentieth century: From triumph to despair. Princeton, NJ: Princeton University Press.

Dweik, B. S. (1992). Lebanese Christians in Buffalo: Language maintenance and language shift. In A. Rouchdy 
Alsahafi, M.

(Ed.), The Arabic language in America (pp. 100-118). Detroit: Wayne State University Press.

Dweik, B., Nofal, M. \& Qawasmeh, R. (2014). Language use and language attitudes among the Muslim Arabs of Vancouver/Canada: A sociolinguistic study. International Journal of Linguistics and Communication, 2 , 75-99.

Dweik, B. \& Qawar, H. (2015). Language choice and language attitudes in a multilingual Arab Canadian community, Quebec- Canada: A sociolinguistic study. British Journal of English Linguistics, 3, 1-12.

Elkholy, A. A. (1966). The Arab Moslems in the United States: Religion and assimilation. New Haven, CN: College and University Press.

Harp, A. R. (1998). Arab American parents' perceptions concerning multicultural education. Unpublished $\mathrm{PhD}$ Dissertation, Wayne State University, Detroit, Michigan.

Judge, A. (2000). France: One state, one nation, one language? In S. Barbour \& C. Carmichael (Eds.), Language and nationalism in Europe (pp. 44-82). Oxford: Oxford University Press.

Kipp, S. (2008). The language ecology of Australia's community languages. In A. Creese, P. Martin \& N. H. Hornberger (Eds.), Encyclopedia of language and education (2nd ed., Vol. 9: Ecology of language, pp. 69-83). New York: Springer Science+Business Media LLC. https://doi.org/10.1007/978-0-387-30424-3_222

Lewis, G. J. (1982). Human migration. London: Croom Helm.

Meilaender, P. C. (2001). Toward a theory of immigration. New York: Palgrave. https://doi.org/10.1057/9780312299118

Muhr, R. (2012). Non-dominant varieties of pluricentric languages. Getting the picture; in memory of Michael Clyne. Frankfurt am Main: Lang. https://doi.org/10.3726/978-3-653-01621-5

Rouchdy, A. (1992). The Arabic language in America. Detroit: Wayne State University Press.

Rouchdy, A. (2002). Language conflict and identity: Arabic in the American diaspora. In A. Rouchdy (Ed.), Language contact and language conflict in Arabic: Variations on a sociolinguistic theme (pp. 133-148). London: RoutledgeCurzon.

Sawaie, M. (1992). Arabic in the melting pot: Will it survive? In A. Rouchdy (Ed.), The Arabic language in America (pp. 83-99). Detroit: Wayne State University Press.

Sawaie, M., \& Fishman, J. A. (1985). Arabic-language maintenance efforts in the United States. Journal of Ethnic Studies, 13, 33-49.

Statistics Canada. (2011). Census of Population and dwellings. http://www.statcan.gc.ca/eng

Statistics New Zealand. (2002). Census of Population and Dwellings (Ethnic groups). http://www.stats.govt.nz.

Statistics New Zealand. (2013). New Zealand Census of Population and Dwellings: Language spoken (Total responses). http://www.stats.govt.nz.

Taft, R., \& Cahill, D. (1989). Mother tongue maintenance in Lebanese immigrant families in Australia. Journal of Multilingual and Multicultural Development, 10, 129-143. https://doi.org/10.1080/01434632.1989.9994369

Tayash, F. A., \& Ayouby, K. K. (1992). Arab-American media: Past and present. In A. Rouchdy (Ed.), The Arabic language in America (pp. 162-183). Detroit: Wayne State University Press. 